\title{
Soil quality in corn cultivation using bamboo biochar, compost, and phonska
}

\author{
Yohanes $P$ Situmeang ${ }^{1}$ \\ ${ }^{1}$ Universitas Warmadewa, Agriculture Faculty, Denpasar-Bali, Indonesia
}

\begin{abstract}
This study aims to determine the status of soil quality after biochar treatment, compost, and phonska in the cornfield. Soil samples were taken from 48 experimental plots after harvesting of maize. Assessment of soil quality is done by collecting selected indicator data including soil physical and chemical properties to observe changes in soil due to land use and agricultural cultivation practices. The soil quality status in this study was determined by calculating the value of soil quality rating (SQR) based on the weighting of 11 indicators of soil quality. The results showed that soil quality before the research was bad (SQR 30) and improved to moderate (SQR 27) until a good (SQR 20) after the research of biochar, compost and NPK phonska on the cornfield. Improved soil quality in biochar formulations $10.52 \mathrm{t}$ ha-1, compost, and phonska, due to improved soil physical properties such as porosity, bulk density, and soil moisture content, which has encouraged the process of exchange and chemical reactions in the soil to release nutrients for the plant. Giving of bamboo biochar, compost, and NPK phonska on dry land cultivated maize has resulted in good soil quality (SQR 20) or approaching sustainability status is very good (highly sustainable).
\end{abstract}

\section{Introduction}

Sustainable agriculture is an effort made to maintain the productivity and quality of the land. Soil qualities are defined as soil capacity to function in ecosystems and land use limits, to maintain biological productivity, maintain environmental quality, and plant and animal health [1]. The quality of land in agriculture, referring to the ability of the soil to maintain production. High soil quality is associated with efficient water use, nutrition and pesticides, water and air quality improvement, greenhouse gas emissions mitigation, and increased agronomic production [2]. Soil quality cannot be measured directly, but static or dynamic soil quality indicators or measurable land attributes are generally affected by land use and soil management practices [35].

Soil physical and chemical properties can be used as indicators of soil quality assessment and sustainability of agricultural systems. Several sets of minimum data have been proposed to quantitatively assess the sustainability of soil management practices [6]. The criteria used for the sustainability of agricultural systems are based on the critical limits of the main soil properties in relation to the threshold value beyond which productivity is greatly reduced or drastic environmental impact $[2,5]$. The determination of soil quality rating (SQR) based on the sum of the value and weight of each soil quality indicator can be used in soil quality rating [2].

Currently, balanced fertilization using organic and inorganic fertilizers to maintain soil fertility is still not fully applied to agricultural cultivation systems. Some research on balanced fertilization application has been done, such as by [7-9], by using biochar, compost and NPK phonska in the dry land can increase growth and yield of corn, and can improve physical and chemical properties in the soil. However, the dynamics of changes in soil properties still need to be assessed for soil quality to determine the sustainability of land use and agricultural systems. Based on the above description, this study aims to determine the status of soil quality and the sustainability of agricultural cultivation system on corn fields applied with biochar, compost, and Phonska.

\section{Materials and methods}

The materials used in this research are bamboo biochar, compost, NPK phonska, and soil samples. The soil sample is taken from the dry land of Sulahan Village, District of Susut, Bangli Regency. Analysis of physical and chemical properties of soil was carried out in the laboratory of Soil Science, Agriculture Faculty, Udayana University and the laboratory of Agricultural Faculty, Warmadewa University.

This research uses factorial randomized block design with 2 factors. The first factor was the dose of biochar (D) with four levels (without biochar, $5.26 \mathrm{t} \mathrm{ha}^{-1}, 10.52 \mathrm{t}$ $\mathrm{ha}^{-1}$, and $\left.15.78 \mathrm{tha}^{-1}\right)$. The second factor is the type of fertilizer $(\mathrm{P})$ with four types (without fertilizer, compost, phonska, and compost+NPK phonska). The treatment was repeated three times to obtain 48 plot experiments. After harvesting the maize [8], 48 of these experimental

\footnotetext{
* Corresponding author: yohanes@,warmadewa.ac.id
} 
plots were taken soil samples for testing soil properties in the laboratory and soil quality assessments.

The land quality assessment is conducted by collecting selected indicator data including physical and soil chemistry data (Table 1) and the use of such data to observe changes in soil due to land use change and management practices with reference to [2]. The limiting factor and the relative weighting of the 11 minimum data sets (MDS) indicator of soil quality are presented in Table 1.

Table 1. Relative weighting factors (RWF) and critical levels for some soil properties $[2,10]$.

\begin{tabular}{|l|c|c|c|c|c|}
\hline Indicator & \multicolumn{5}{|c|}{ Limitation dan Relative weighting factors (RWF) } \\
\hline & None & Slight & Moderate & Severe & Extreme \\
\cline { 2 - 6 } & 1 & 2 & 3 & 4 & 5 \\
\hline 1. Water content (\%) & $>30$ & $20-30$ & $8-20$ & $1.5-1.6$ & $<2$ \\
\hline 2. Bulk Density (g.cm $\left.{ }^{-3}\right)$ & $<1.3$ & $1.3-1.4$ & $1.4-1.5$ & $10-15$ & $<10$ \\
\hline 3. Porosity (\%) & $>20$ & $18-20$ & $15-18$ & SiC, LS & S, C \\
\hline 4. Soil Texture & $\mathrm{L}$ & SiL, Si, SiCL & CL, SL & $5.0-5.4$ or 7.8-8.2 & $<5.0$ or $>8.2$ \\
\hline 5. pH & $6-7$ & $5.8-6.0$ or 7.0-7.4 & $5.4-5.8$ or 7.4-7.8 & $0.5-1.0$ & $<0.5$ \\
\hline 6. C-Organic (\%) & $5-10$ & $3-5$ & $1-3$ & $0.1-0.2$ & $<0.1$ \\
\hline 7. N-total (\%) & $>0.75$ & $0.51-0.75$ & $0.21-0.50$ & $10-15$ & $<10$ \\
\hline 8. P-available (ppm) & $>35$ & $26-35$ & $16-25$ & $78-117$ & $<78$ \\
\hline 9. K-available (ppm) & $>390$ & $234-390$ & $156-195$ & $5-16$ & $<5$ \\
\hline 10. CEC (me100g-1) & $>40$ & $25-40$ & $36-24$ & $20-35$ & $<20$ \\
\hline 11. BS (\%) & $>70$ & $51-70$ & & & \\
\hline
\end{tabular}

$\mathrm{L}$ is loam; $\mathrm{SiL}$ is silt loam; $\mathrm{SiCL}$ is silty clay loam; $\mathrm{CL}$ is clay loam; $\mathrm{SL}$ is sandy loam; $\mathrm{SiC}$ is silty clay;

LS is loamy sand; $\mathrm{C}$ is clay; $\mathrm{S}$ is sand, CEC is cation exchange capacity, BS is base saturation.

The minimum data sets that are the key characteristics of soil quality in the topical area, consist of (1) physical characteristic: moisture content, volume weight, porosity, and soil texture, (2) chemical identification: $\mathrm{pH}, \mathrm{C}$-organic, nutrient availability ( $\mathrm{P}$ and $\mathrm{K}), \mathrm{CEC}$, and BS. The soil quality indicator is selected from soil properties indicating the capacity of the soil function or limiting factor for crop yield. The limiting factor or relative weighting factor (RWF) ranges from no limiting to extreme factor with weighting on a scale of 1 to 5 (Tables 1 and 2). The upper limit (weight 5) for soil properties with many limiting factors means that the soil quality is very bad and unsustainable, and the lower limit (weight 1) for soil properties that do not have limiting factors means soil quality is very good and sustainable.

Table 2. The sustainability of the agricultural system is related to the SQR based on 11 MDS [2].

\begin{tabular}{|l|c|c|}
\hline Sustainability (soil quality) & RWF & SQR \\
\hline Highly sustainable (very good) & 1 & $<20$ \\
\hline Sustainable (good) & 2 & $20-25$ \\
\hline Sustainable with high input (moderate) & 3 & $25-30$ \\
\hline Sustainable with another land use (bad) & 4 & $30-40$ \\
\hline Unsustainable (very bad) & 5 & $>40$ \\
\hline
\end{tabular}

Soil quality status was determined by calculating the value of soil quality rating (SQR) based on the sum of the weight of the value of each indicator of soil quality. Furthermore, the SQR value associated with the sustainability of agricultural systems according to [2] compared to the soil quality status criteria based on 11 Minimum Data Sets is presented in Table 2. This SQR value ranges from 20-40, the lower the SQR value the soil properties become the limiting factor less so the better the soil quality.

\section{Results}

\subsection{Characteristics of soil, bamboo biochar, and compost}

Sulahan Village, Susut Sub-district, Bangli District was chosen as a research location because it has a large dry land potential to be developed for food crops, especially corn crops. Research location with soil type regosol humus with the altitude of place $762 \mathrm{~m}$ asl, while characteristic of physical and chemical of soil location of research before experiment presented in Table 3.

Table 3. Results of soil analysis, RWF, and SQR before the experiment [7].

\begin{tabular}{|c|c|c|}
\hline Treatment & Soil & RWF \\
\hline WC (\%) & 6.19 & 4 \\
\hline Texture & 9.60 & 3 \\
\hline BD $\left(\mathrm{g} \mathrm{cm}^{-3}\right)$ & 0.97 & 1 \\
\hline Porosity (\%) & 63.54 & 1 \\
\hline $\mathrm{pH}$ & 6.82 & 1 \\
\hline $\mathrm{C}(\%)$ & 2.69 & 3 \\
\hline $\mathrm{N}(\%)$ & 0.19 & 4 \\
\hline $\mathrm{P}(\mathrm{ppm})$ & 31.08 & 2 \\
\hline $\mathrm{K}(\mathrm{ppm})$ & 31.75 & 5 \\
\hline $\mathrm{CEC}\left(\mathrm{cmol}(+) \mathrm{kg}^{-1}\right)$ & 16.10 & 4 \\
\hline $\mathrm{BS}(\%)$ & 55.89 & 2 \\
\hline $\mathrm{SQR}$ & & 30 \\
\hline
\end{tabular}

The result of soil physical and chemical properties analysis in Table 3 shows that the research field has bad soil quality with $\mathrm{SQR}$ value of 30 . Poor soil quality status can be improved through the provision of organic materials such as biochar and compost or inorganic such 
as phonska. The results of characteristic analysis of biochar and compost are presented in Table 4.

Table 4. Characteristics of biochar and compost [7].

\begin{tabular}{|c|c|c|}
\hline Analysis Type & Biochar & Compost \\
\hline $\mathrm{pH}$ & 7.48 & 7.35 \\
\hline $\mathrm{EC}\left(\mathrm{mmhos} \mathrm{cm}^{-1}\right)$ & 0.77 & 10.92 \\
\hline $\mathrm{C}(\%)$ & 3.08 & 15.51 \\
\hline $\mathrm{N}(\%)$ & 0.06 & 0.82 \\
\hline $\mathrm{C} / \mathrm{N}$ & 51.33 & 18.91 \\
\hline $\mathrm{P}(\mathrm{ppm})$ & 451.78 & 650.14 \\
\hline $\mathrm{K}(\mathrm{ppm})$ & 36.07 & 23.26 \\
\hline $\mathrm{Ca}\left(\mathrm{mg} \mathrm{kg}^{-1}\right)$ & 32.20 & 9.28 \\
\hline $\mathrm{Mg}\left(\mathrm{mg} \mathrm{kg}^{-1}\right)$ & 15.88 & 15.16 \\
\hline $\mathrm{Na}\left(\mathrm{mg} \mathrm{kg}^{-1}\right)$ & 14.62 & 15.26 \\
\hline $\mathrm{WC}(\%)$ & 5.48 & 22.47 \\
\hline
\end{tabular}

Table 4 shows that biochar has a $\mathrm{pH}$ of $\mathrm{H} 2 \mathrm{O}, \mathrm{C} / \mathrm{N}, \mathrm{K}$, $\mathrm{Ca}$, and $\mathrm{Mg}$ relatively higher than in compost, otherwise compost has EC, C-organic, N-total, $\mathrm{P}$-available, Na, and relative water content higher than biochar. Both types of organic materials, biochar and compost have different characteristics, but these two materials have the same purpose and complement each other in improving soil properties in dry land, ie increasing the ability of soil in storing water and nutrients, increasing porosity and decreasing the weight of volume soil, increase Corganic, N, P, K, CEC, and BS in the soil.

\subsection{Soil quality rating (SQR)}

The soil quality rating is calculated based on the total number of selected soil quality indicators as the minimum data set [2]. A minimum data set consisting of 11 selected soil physical and chemical properties determines the status of soil quality. The results of the SQR measurements or the soil quality ratings from each of the biochar dose combination treatments and with the type of fertilizer (DP) on the soil after the study can be seen in Table 5.

Table 5. Soil analysis, relative weighting factors (RWF), and soil quality rating (SQR) on biochar dosage treatment and type of fertilizer after the experiment.

\begin{tabular}{|c|c|c|c|c|c|c|c|c|c|c|c|c|}
\hline \multirow{2}{*}{ Treatment } & WC & Texture & $\mathrm{BD}$ & Porosity & $\mathrm{pH}$ & $\mathrm{C}$ & $\mathrm{N}$ & $\mathrm{P}$ & K & CEC & BS & \multirow{2}{*}{ SQR } \\
\hline & $\%$ & & $\mathrm{~g} \mathrm{~cm}^{-3}$ & $\%$ & & $\%$ & $\%$ & $\mathrm{ppm}$ & ppm & $\operatorname{cmol}(+) \mathrm{kg}^{-1}$ & $\%$ & \\
\hline $\mathrm{D}_{0} \mathrm{P}_{0}$ & $\begin{array}{c}7.04 \\
(4)\end{array}$ & $\begin{array}{c}11.68 \\
(3)\end{array}$ & $\begin{array}{c}0.99 \\
(1)\end{array}$ & $\begin{array}{c}62.66 \\
(1)\end{array}$ & $\begin{array}{c}6.62 \\
(1)\end{array}$ & $\begin{array}{c}3.35 \\
(2)\end{array}$ & $\begin{array}{c}0.13 \\
(4)\end{array}$ & $\begin{array}{c}30.49 \\
(2)\end{array}$ & $\begin{array}{c}444.07 \\
\text { (1) }\end{array}$ & $\begin{array}{c}15.46 \\
(4)\end{array}$ & $\begin{array}{c}23.83 \\
(4)\end{array}$ & 27 \\
\hline $\mathrm{D}_{0} \mathrm{P}_{1}$ & $\begin{array}{c}8.38 \\
(3)\end{array}$ & $\begin{array}{c}9.08 \\
(3)\end{array}$ & $\begin{array}{c}0.92 \\
(1)\end{array}$ & $\begin{array}{c}65.23 \\
(1)\end{array}$ & $\begin{array}{r}6.63 \\
(1)\end{array}$ & $\begin{array}{c}3.64 \\
(2)\end{array}$ & $\begin{array}{c}0.17 \\
(4)\end{array}$ & $\begin{array}{c}40.65 \\
(1)\end{array}$ & $\begin{array}{c}746.98 \\
\text { (1) }\end{array}$ & $\begin{array}{c}17.15 \\
(3)\end{array}$ & $\begin{array}{c}35.96 \\
(4)\end{array}$ & 24 \\
\hline $\mathrm{D}_{0} \mathrm{P}_{2}$ & $\begin{array}{c}8.77 \\
(3)\end{array}$ & $\begin{array}{c}15.72 \\
(3)\end{array}$ & $\begin{array}{c}0.97 \\
(1)\end{array}$ & $\begin{array}{c}63.58 \\
(1)\end{array}$ & $\begin{array}{c}6.66 \\
(1)\end{array}$ & $\begin{array}{c}3.84 \\
(2)\end{array}$ & $\begin{array}{c}0.19 \\
(4)\end{array}$ & $\begin{array}{c}35.98 \\
(1)\end{array}$ & $\begin{array}{c}331.41 \\
(2)\end{array}$ & $\begin{array}{c}17.18 \\
(3)\end{array}$ & $\begin{array}{c}49.76 \\
\text { (3) }\end{array}$ & 24 \\
\hline $\mathrm{D}_{0} \mathrm{P}_{3}$ & $\begin{array}{c}9.16 \\
(3)\end{array}$ & $\begin{array}{c}13.00 \\
(3)\end{array}$ & $\begin{array}{l}0.97 \\
(1)\end{array}$ & $\begin{array}{c}63.38 \\
(1)\end{array}$ & $\begin{array}{c}6.55 \\
(1)\end{array}$ & $\begin{array}{c}3.71 \\
(2)\end{array}$ & $\begin{array}{c}0.21 \\
(3)\end{array}$ & $\begin{array}{c}49.34 \\
\text { (1) }\end{array}$ & $\begin{array}{c}605.67 \\
(1)\end{array}$ & $\begin{array}{c}13.91 \\
(4)\end{array}$ & $\begin{array}{c}61.64 \\
(2)\end{array}$ & 22 \\
\hline $\mathrm{D}_{1} \mathrm{P}_{0}$ & $\begin{array}{c}8.64 \\
(3)\end{array}$ & $\begin{array}{l}8.72 \\
(3)\end{array}$ & $\begin{array}{c}0.91 \\
(1)\end{array}$ & $\begin{array}{c}65.56 \\
(1)\end{array}$ & $\begin{array}{c}6.72 \\
(1)\end{array}$ & $\begin{array}{c}3.82 \\
(2)\end{array}$ & $\begin{array}{c}0.16 \\
(4)\end{array}$ & $\begin{array}{c}32.76 \\
(2)\end{array}$ & $\begin{array}{c}674.56 \\
(1)\end{array}$ & $\begin{array}{c}16.17 \\
(4)\end{array}$ & $\begin{array}{c}37.14 \\
(3)\end{array}$ & 25 \\
\hline $\mathrm{D}_{1} \mathrm{P}_{1}$ & $\begin{array}{c}9.43 \\
(3)\end{array}$ & $\begin{array}{l}15.59 \\
(3)\end{array}$ & $\begin{array}{c}0.91 \\
(1)\end{array}$ & $\begin{array}{l}65.51 \\
(1)\end{array}$ & $\begin{array}{l}6.76 \\
\text { (1) }\end{array}$ & $\begin{array}{c}4.24 \\
(2)\end{array}$ & $\begin{array}{l}0.18 \\
(4)\end{array}$ & $\begin{array}{c}42.56 \\
\text { (1) }\end{array}$ & $\begin{array}{c}997.94 \\
(1)\end{array}$ & $\begin{array}{c}17.55 \\
(3)\end{array}$ & $\begin{array}{c}39.86 \\
\text { (3) }\end{array}$ & 23 \\
\hline $\mathrm{D}_{1} \mathrm{P}_{2}$ & $\begin{array}{c}8.96 \\
(3)\end{array}$ & $\begin{array}{c}10.39 \\
(3)\end{array}$ & $\begin{array}{c}0.95 \\
(1)\end{array}$ & $\begin{array}{c}64.07 \\
(1)\end{array}$ & $\begin{array}{c}6.77 \\
(1)\end{array}$ & $\begin{array}{c}3.87 \\
(2)\end{array}$ & $\begin{array}{c}0.18 \\
(4)\end{array}$ & $\begin{array}{c}64.70 \\
(1)\end{array}$ & $\begin{array}{c}710.76 \\
(1)\end{array}$ & $\begin{array}{l}17.48 \\
(3)\end{array}$ & $\begin{array}{c}35.99 \\
(3)\end{array}$ & 23 \\
\hline $\mathrm{D}_{1} \mathrm{P}_{3}$ & $\begin{array}{c}9.36 \\
(3)\end{array}$ & $\begin{array}{l}9.08 \\
(3)\end{array}$ & $\begin{array}{c}0.93 \\
(1)\end{array}$ & $\begin{array}{c}64.99 \\
(1)\end{array}$ & $\begin{array}{c}6.63 \\
(1)\end{array}$ & $\begin{array}{c}4.08 \\
(2)\end{array}$ & $\begin{array}{c}0.18 \\
(4)\end{array}$ & $\begin{array}{c}37.09 \\
\text { (1) }\end{array}$ & $\begin{array}{c}934.42 \\
(1)\end{array}$ & $\begin{array}{c}16.87 \\
(4)\end{array}$ & $\begin{array}{c}65.12 \\
(2)\end{array}$ & 23 \\
\hline $\mathrm{D}_{2} \mathrm{P}_{0}$ & $\begin{array}{c}9.22 \\
(3)\end{array}$ & $\begin{array}{c}11.68 \\
(3)\end{array}$ & $\begin{array}{c}0.90 \\
(1)\end{array}$ & $\begin{array}{c}66.07 \\
(1)\end{array}$ & $\begin{array}{c}6.74 \\
\text { (1) }\end{array}$ & $\begin{array}{c}3.42 \\
(2)\end{array}$ & $\begin{array}{c}0.19 \\
\text { (4) }\end{array}$ & $\begin{array}{c}26.00 \\
(3)\end{array}$ & $\begin{array}{c}947.19 \\
(1)\end{array}$ & $\begin{array}{c}16.19 \\
(4)\end{array}$ & $\begin{array}{c}29.69 \\
(4)\end{array}$ & 26 \\
\hline $\mathrm{D}_{2} \mathrm{P}_{1}$ & $\begin{array}{c}9.71 \\
(3)\end{array}$ & $\begin{array}{c}11.69 \\
(3)\end{array}$ & $\begin{array}{c}0.89 \\
(1)\end{array}$ & $\begin{array}{c}66.30 \\
(1)\end{array}$ & $\begin{array}{c}6.68 \\
(1)\end{array}$ & $\begin{array}{c}3.84 \\
(2)\end{array}$ & $\begin{array}{r}0.17 \\
(4)\end{array}$ & $\begin{array}{c}68.06 \\
(1)\end{array}$ & $\begin{array}{c}1010.59 \\
\text { (1) }\end{array}$ & $\begin{array}{c}18.67 \\
(3)\end{array}$ & $\begin{array}{c}63.69 \\
(2)\end{array}$ & 22 \\
\hline $\mathrm{D}_{2} \mathrm{P}_{2}$ & $\begin{array}{c}9.87 \\
(3)\end{array}$ & $\begin{array}{l}9.09 \\
(3)\end{array}$ & $\begin{array}{c}0.89 \\
(1)\end{array}$ & $\begin{array}{c}66.45 \\
(1)\end{array}$ & $\begin{array}{c}6.75 \\
(1)\end{array}$ & $\begin{array}{c}3.83 \\
(2)\end{array}$ & $\begin{array}{c}0.20 \\
(3)\end{array}$ & $\begin{array}{c}38.99 \\
\text { (1) }\end{array}$ & $\begin{array}{c}695.08 \\
(1)\end{array}$ & $\begin{array}{c}17.57 \\
(3)\end{array}$ & $\begin{array}{c}47.69 \\
(3)\end{array}$ & 22 \\
\hline $\mathrm{D}_{2} \mathrm{P}_{3}$ & $\begin{array}{c}10.41 \\
(3)\end{array}$ & $\begin{array}{c}11.29 \\
(3)\end{array}$ & $\begin{array}{c}0.89 \\
(1)\end{array}$ & $\begin{array}{c}66.57 \\
(1)\end{array}$ & $\begin{array}{c}6.79 \\
(1)\end{array}$ & $\begin{array}{c}3.80 \\
(2)\end{array}$ & $\begin{array}{c}0.20 \\
(3)\end{array}$ & $\begin{array}{c}63.38 \\
(1)\end{array}$ & $\begin{array}{c}1247.02 \\
\text { (1) }\end{array}$ & $\begin{array}{c}17.18 \\
(3)\end{array}$ & $\begin{array}{c}71.73 \\
(1)\end{array}$ & 20 \\
\hline $\mathrm{D}_{3} \mathrm{P}_{0}$ & $\begin{array}{c}9.61 \\
(3)\end{array}$ & $\begin{array}{c}12.98 \\
(3)\end{array}$ & $\begin{array}{c}0.88 \\
(1)\end{array}$ & $\begin{array}{c}66.84 \\
(1)\end{array}$ & $\begin{array}{r}6.56 \\
(1)\end{array}$ & $\begin{array}{c}3.41 \\
(2)\end{array}$ & $\begin{array}{r}0.19 \\
(4)\end{array}$ & $\begin{array}{c}38.18 \\
(1)\end{array}$ & $\begin{array}{c}1026.34 \\
\text { (1) }\end{array}$ & $\begin{array}{c}16.57 \\
(4)\end{array}$ & $\begin{array}{c}31.87 \\
(4)\end{array}$ & 25 \\
\hline $\mathrm{D}_{3} \mathrm{P}_{1}$ & $\begin{array}{c}10.40 \\
(3)\end{array}$ & $\begin{array}{c}12.97 \\
(3)\end{array}$ & $\begin{array}{c}0.87 \\
(1)\end{array}$ & $\begin{array}{c}67.31 \\
(1)\end{array}$ & $\begin{array}{c}6.62 \\
(1)\end{array}$ & $\begin{array}{c}3.68 \\
(2)\end{array}$ & $\begin{array}{c}0.18 \\
(4)\end{array}$ & $\begin{array}{c}40.75 \\
(1)\end{array}$ & $\begin{array}{c}1046.57 \\
(1)\end{array}$ & $\begin{array}{c}22.89 \\
\text { (3) }\end{array}$ & $\begin{array}{c}37.74 \\
(3)\end{array}$ & 23 \\
\hline $\mathrm{D}_{3} \mathrm{P}_{2}$ & $\begin{array}{c}9.03 \\
(3)\end{array}$ & $\begin{array}{c}12.98 \\
(3)\end{array}$ & $\begin{array}{l}0.86 \\
(1)\end{array}$ & $\begin{array}{c}67.48 \\
(1)\end{array}$ & $\begin{array}{c}6.79 \\
(1)\end{array}$ & $\begin{array}{c}3.73 \\
(2)\end{array}$ & $\begin{array}{l}0.25 \\
\text { (3) }\end{array}$ & $\begin{array}{c}42.30 \\
\text { (1) }\end{array}$ & $\begin{array}{c}1018.34 \\
\text { (1) }\end{array}$ & $\begin{array}{c}18.04 \\
(3)\end{array}$ & $\begin{array}{c}46.49 \\
\text { (3) }\end{array}$ & 22 \\
\hline $\mathrm{D}_{3} \mathrm{P}_{3}$ & $\begin{array}{c}9.01 \\
(3)\end{array}$ & $\begin{array}{c}10.35 \\
(3)\end{array}$ & $\begin{array}{c}0.87 \\
(1)\end{array}$ & $\begin{array}{c}67.29 \\
(1)\end{array}$ & $\begin{array}{c}6.74 \\
(1)\end{array}$ & $\begin{array}{c}3.77 \\
(2)\end{array}$ & $\begin{array}{c}0.24 \\
(3)\end{array}$ & $\begin{array}{c}41.39 \\
\text { (1) }\end{array}$ & $\begin{array}{c}1100.93 \\
\text { (1) }\end{array}$ & $\begin{array}{c}19.21 \\
(3)\end{array}$ & $\begin{array}{c}22.07 \\
(4)\end{array}$ & 23 \\
\hline
\end{tabular}

$\mathrm{D}_{0}$ (without biochar), $\mathrm{D}_{1}\left(5.26 \mathrm{t} \mathrm{ha}^{-1}\right), \mathrm{D}_{2}\left(10.52 \mathrm{t} \mathrm{ha}^{-1}\right), \mathrm{D}_{3}\left(15.78 \mathrm{t} \mathrm{ha}^{-1}\right), \mathrm{P}_{0}$ (without fertilizer), $\mathrm{P}_{1}$ (compost $\left.20.22 \mathrm{t} \mathrm{ha} \mathrm{h}^{-1}\right), \mathrm{P}_{2}$ (phonska $313.37 \mathrm{~kg} \mathrm{ha}^{-1}$ ), dan $\mathrm{P}_{3}$ (compost+phonska), WC is water content, BD is bulk density, CEC is cation exchange capacity, BS is base saturation, SQR: $<20=$ very good, $20-25=$ good, $25-30=$ moderate, $30-40=$ bad, $>40=$ very bad. 


\section{Discussion}

Assessment of soil quality before the research obtained SQR value 30 (Table 3 ) with bad status. This poor status after the trial can be improved to moderate to good status with a range of SQR values of 20-27 at various biochar doses and fertilizer types (Table 5). In the treatment of $\mathrm{D}_{2} \mathrm{P}_{3}$ (Table 5), the value of SQR 20 (good) or close to the status of sustainability is very good (highly sustainable), whereas in treatment $\mathrm{D}_{0} \mathrm{P}_{0}$ obtained SQR 27 (moderate). The lower the SQR score the better the sustainability index for corn farming in the dry land, the higher the SQR value the worse the sustainability index will be.

Improved soil quality from moderate to $\mathrm{D}_{0} \mathrm{P}_{0}$ treatment to good on $\mathrm{D}_{2} \mathrm{P}_{3}$ treatment is due to biochar and compost according to its characteristics (Table 4) is able to improve soil physical and chemical properties that provide the balance and nutrient adequacy needed by corn crops. Improved soil quality due to biochar $10.52 \mathrm{t} \mathrm{ha}^{-1}$, compost and phonska $\left(\mathrm{D}_{2} \mathrm{P}_{3}\right)$ fertilizers into the soil, starting from improving the quality of soil physical properties such as porosity, bulk density, and soil moisture content, which encourages the increasing process of exchange and reaction chemical in the soil to provide nutrients for plants.

Improved soil moisture due to biochar and compost treatment resulted in soil porosity $\left(\mathrm{r}=0.65^{*}\right)$ and $\mathrm{K}$ - available $\left(\mathrm{r}=0.67^{*}\right)$ was positively and significantly correlated, but the soil bulk density $\left(\mathrm{r}=-0.65^{*}\right)$ was negatively correlated. Improved soil porosity due to biochar and compost treatment also caused K-available $\left(\mathrm{r}=0.82^{* *}\right)$ to be positively and highly correlated and CEC $(r=0.63 *)$ was positively and tangibly correlated, but otherwise the bulk density was negatively correlated with $\mathrm{K}$ - is available $\left(\mathrm{r}=-0.82^{* *}\right)$ and has a negative and real correlation with CEC $\left(r=-0.63^{*}\right)$ (Table 6). This is in line with $[9,11]$, that soil quality improvement due to biochar treatment is supported by the physical characteristics of biochar morphology in SEM 2000x enlargement with the surface area and micropore structure scattered on the biochar surface. These porous biochar pores lead to improved aeration and drainage systems, as well as increased soil ability to absorb ions and water in the soil. Furthermore [12] adds that bamboo biochar has a very microporous structure, with adsorption efficiency about ten times higher than traditional wood biochar. Biochar bamboo can improve aggregation and hold the capacity of groundwater, $\mathrm{pH}$, and CEC soil and increase soil biological activity [13, 14]. Biochar can improve soil carbon capability, maintain soil ecosystem balance, and improve soil fertility, and can act as fertilizer, promote growth and crop yields by providing and maintaining nutrients in the soil $[15,16]$.

Table 6. The coefficient of correlation between soil properties.

\begin{tabular}{|c|c|c|c|c|c|c|c|c|c|c|}
\hline & Water content & Texture & BD & Porosity & $\mathrm{pH}$ & $\mathrm{C}$ & $\mathrm{N}$ & $\mathrm{P}$ & $\mathrm{K}$ & CEC \\
\hline Texture & 0.10 & & & & & & & & & \\
\hline BD & $-0.65^{*}$ & 0.11 & & & & & & & \\
\hline Porosity & $0.65^{*}$ & -0.11 & -1.00 & & & & & & \\
\hline $\mathrm{pH}$ & 0.18 & -0.11 & -0.36 & 0.36 & & & & & & \\
\hline $\mathrm{C}$ & 0.34 & 0.07 & -0.03 & 0.03 & 0.37 & & & & & \\
\hline $\mathrm{N}$ & 0.40 & 0.13 & -0.55 & 0.55 & 0.35 & 0.16 & & & & \\
\hline $\mathrm{P}$ & 0.41 & -0.01 & -0.07 & 0.07 & 0.23 & 0.34 & 0.10 & & & \\
\hline $\mathrm{K}$ & $0.67^{*}$ & -0.06 & $-0.82^{* *}$ & $0.82^{* *}$ & 0.32 & 0.15 & 0.44 & 0.32 & & \\
\hline $\mathrm{CEC}$ & 0.49 & 0.08 & $-0.63^{*}$ & $0.63^{*}$ & 0.19 & 0.18 & 0.20 & 0.16 & 0.47 & \\
\hline $\mathrm{BS}$ & 0.50 & 0.03 & 0.03 & -0.03 & 0.00 & 0.47 & 0.12 & 0.54 & 0.16 & -0.12 \\
\hline \multicolumn{2}{|l|}{$\mathrm{r}(0.05,10,1)=0.576$} & & & $\mathrm{r}(0.01,10,1)=0.708$ \\
\hline
\end{tabular}

\section{Conclusions}

The quality of the soil prior to the study had a bad status (SQR 30) and after the biochar, compost and NPK phonska studies had improved to moderate status (SQR 27) to good (SQR 20). Giving bamboo biochar $10.52 \mathrm{t}$ ha $^{-1}$ along with compost $20.22 \mathrm{t} \mathrm{ha}^{-1}$ and NPK phonska $313.37 \mathrm{~kg} \mathrm{ha}^{-1}$ has yielded good soil quality (SQR 20) or approaching highly sustainable status dry land cultivated corn crops.

Thanks to the Kemenristekdikti DRPM who helped fund the research in 2016. Thanks also to the students and laboratory analysts who have helped this research.

\section{References}

1. J W Doran and T B Parkin, Defining and assessing soil quality p. 3-21 In: J.W. Doran et al., (ed.) Defining Soil Quality for a Sustainable Environment. SSSA Spec. Publ. No. 35, Soil Sci. Soc. Am., Inc. and Am. Soc. Agron., Inc., Madison. (1994)

2. R Lal No. 631.4 L193m. 85p (Washington US: Soil Management Support Services, 1994)

3. C A Seybold, M J Mausbach, D L Karlen, and H H Rogers, Quantification of soil quality p 387-404 In: R. Lal, et al (Eds.) Soil Processes and the Carbon Cycle. (CRC Press, Boca Raton, 1998)

4. M Sanchez-Maranon, M Soriano, G Delgado, and R Delgado Soil Science Society of America Journal 663 p948-958 (2002)

5. M K Shukla, R Lal, and M Ebinger, Soil Tillage 
Research 872 p194-204 (2006)

6. W E Larson and F J Pierce, The dynamics of soil quality as a measure of sustainable management p37-51, (1994)

7. Y P Situmeang, I M Adnyana, I N N Subadiyasa, and I N Merit, Int. J. on Advanced Science, Engineering and Information Technology 56 p433439 (2015)

8. Y P Situmeang Doctoral dissertation p174 (Universitas Udayana, 2017)

9. Y P Situmeang, Int. Research J of Engineering, IT \& Scientific Research (IRJEIS) 33 p38-48 (2017)

10. Balai Penelitian Tanah. Badan Penelitian Pengembangan Pertanian p136 (Departemen Pertanian. Bogor, 2009)

11. Y P Situmeang $\mathrm{J}$ of Biological and Chemical Research 342 p704-712 (2017)

12. L Hua, W Wu, Y Liu, M B McBride, and Y Chen Environmental Science and Pollution Research 16 p1-9 (2009)

13. K Y Chan, B L Van-Zwieten, I Meszaros, D Downie, and S Joseph, Australian $J$ of Soil Research 46 p437- 444 (2007)

14. A Masulili, W H Utomo, and Syekhfani $J$ of Agriculture Science 3 p25-33 (2010)

15. J Major, C Steiner, A Ditommaso, N P Falcao, and J Lehmann, Weed Biol Manag 5 p69-76 (2005)

16. C Steiner, W Teixeira, J Lehmann, T Nehls, J DeMacdo, W Blum, and W Zech, Plant and Soil 291 p275-290 (Springer Netherlands, 2007) 